Article

\title{
Tensile and Creep Testing of Sanicro 25 Using Miniature Specimens
}

\author{
Petr Dymáček ${ }^{1,2, *}$, Milan Jarý ${ }^{1}$, Ferdinand Dobeš ${ }^{1}$ and Luboš Kloc ${ }^{1}$ \\ 1 Institute of Physics of Materials, Academy of Sciences of the Czech Republic, Žižkova 22, CZ-61662 Brno, \\ Czech Republic; jary@ipm.cz (M.J.); dobes@ipm.cz (F.D.); kloc@ipm.cz (L.K.) \\ 2 CEITEC IPM, Institute of Physics of Materials, Academy of Sciences of the Czech Republic, Žižkova 22, \\ CZ-61662 Brno, Czech Republic \\ * Correspondence: pdymacek@ipm.cz; Tel.: +420-532-290-411
}

Received: 21 December 2017; Accepted: 12 January 2018; Published: 16 January 2018

\begin{abstract}
Tensile and creep properties of new austenitic steel Sanicro 25 at room temperature and operating temperature $700{ }^{\circ} \mathrm{C}$ were investigated by testing on miniature specimens. The results were correlated with testing on conventional specimens. Very good agreement of results was obtained, namely in yield and ultimate strength, as well as short-term creep properties. Although the creep rupture time was found to be systematically shorter and creep ductility lower in the miniature test, the minimum creep rates were comparable. The analysis of the fracture surfaces revealed similar ductile fracture morphology for both specimen geometries. One exception was found in a small area near the miniature specimen edge that was cut by electro discharge machining, where an influence of the steel fracture behavior at elevated temperature was identified.
\end{abstract}

Keywords: Sanicro 25; austenitic steel; miniature tensile test; creep; fracture

\section{Introduction}

Mechanical testing on miniature specimens is becoming increasingly important for several reasons. It can be used for testing irradiated materials to minimize the radiation dose, determining the local properties of weld zones or the remaining life of service exposed parts, the development of new materials available in limited amounts, etc. Different specimen geometries have been introduced in the past for tensile, fracture, and creep properties determination [1-6], including the well-known small punch test (SPT) and small punch creep test (SPC) [7-20]. The typical shape of the small punch specimen is most often a disc of $8 \mathrm{~mm}$ diameter or a square $10 \times 10 \mathrm{~mm}$ and $0.5 \mathrm{~mm}$ thickness. The advantage of SPT or SPC is the need of higher forces for penetration of the disc (due to higher effective cross-section) in comparison to forces needed for testing a uniaxial miniature tensile specimen of cross-section in range of 0.5 to $2 \mathrm{~mm}^{2}$. A certain disadvantage of SPT and SPC is the equibiaxial stress state that makes correlation with uniaxial tests more complicated. The use of tensile specimens of similar size to an SP disc called a micro-tensile test (M-TT) was demonstrated in [21-23] with promising results. It has also been demonstrated that the flat specimens can represent the tensile curve well up to the necking point, and the ductility is influenced only by the post-necking region [1]. The use of a protective inert atmosphere is inevitable for testing miniature specimens at high temperatures to prevent specimen oxidation. The application of creep tests to miniature specimens is primarily intended for accelerated testing-mainly remaining life or local properties determination. It would hardly replace conventional long-term creep tests, and therefore a reasonable length of such an experiment is within the $1000 \mathrm{~h}$ range.

The aim of this study is to obtain tensile and creep properties using miniature tensile specimens prepared from the same $D_{\mathrm{s}}=8 \mathrm{~mm}$, similar to the SPT disc size, and correlate the results with measurements on standard specimens for the prospective austenitic steel Sanicro 25. This should 
demonstrate the potential of miniature specimen testing methods to investigate the mechanical properties of new materials at room and elevated temperatures.

\section{Materials and Methods}

Austenitic steel of grade UNS S31035, Sanicro 25 [24], was selected as an experimental material for the study. It was produced by Sandvik (Sandviken, Sweden) in the form of a seamless tube of $38 \mathrm{~mm}$ in diameter and wall thickness of $8.8 \mathrm{~mm}$, heat no. 527207, and lot no. 24476. It was supplied to Doosan Babcock Energy Ltd. (Renfrew, UK) and part of the tube was provided to Institute of Physics of Materials, ASCR (IPM) for creep testing within the European Virtual Institute on Knowledge-based Multifunctional Materials (KMM-VIN) research activities [25]. The chemical composition is shown in Table 1. The experimental material was used in the as-received state after solution annealing $1220{ }^{\circ} \mathrm{C} / 5 \mathrm{~min} /$ cooled in water. A fine twinned austenitic microstructure of the steel is shown in Figure 1a. It contains grains with average size of about $25 \mu \mathrm{m}$, but grains with size of up to $200 \mu \mathrm{m}$ are also present in the microstructure, as shown in Figure 1b. The grain boundaries are decorated with $\mathrm{Nb}$-rich carbonitrides of typical size $200 \mathrm{~nm}$, as reported in [26,27]. The carbonitrides are also present in the interior of larger grains, and their chemistry is also discussed in [26,27]. Sanicro 25 shows very good creep and fatigue resistance at high temperatures up to $700^{\circ} \mathrm{C}$, as well as oxidation resistance $[24,28]$. Significant strain hardening and cyclic strain hardening of the steel has been demonstrated due to interaction of the dislocations with about 50-nm nanoclusters at high temperatures [24,29].

Table 1. Chemical composition of Sanicro 25.

\begin{tabular}{cccccccc}
\hline Element & $\mathbf{C}$ & $\mathbf{N i}$ & $\mathbf{C r}$ & $\mathbf{W}$ & $\mathbf{C o}$ & $\mathbf{C u}$ & $\mathbf{M n}$ \\
\hline wt $\%$ & 0.064 & 25.36 & 22.35 & 3.37 & 1.44 & 2.98 & 0.51 \\
\hline Element & $\mathbf{N b}$ & $\mathbf{N}$ & $\mathbf{S i}$ & $\mathbf{N}$ & $\mathbf{P}$ & $\mathbf{B}$ & $\mathbf{F e}$ \\
\hline wt $\%$ & 0.49 & 0.23 & 0.18 & 0.23 & 0.016 & 0.0035 & balance \\
\hline
\end{tabular}

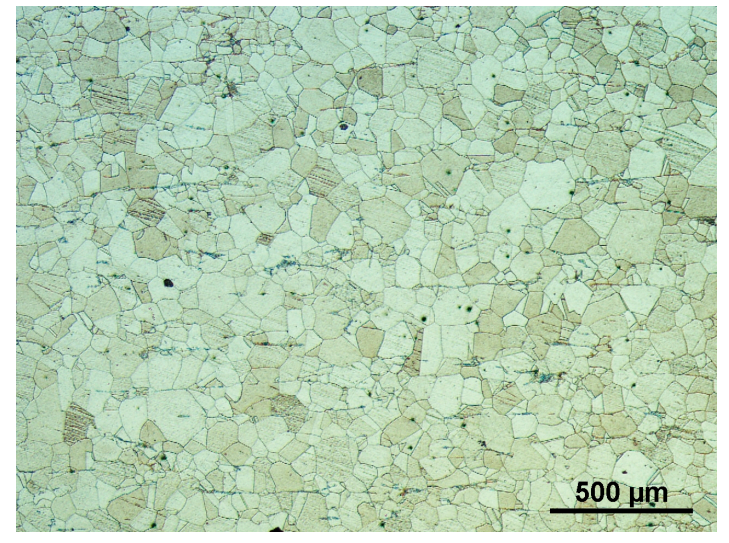

(a)

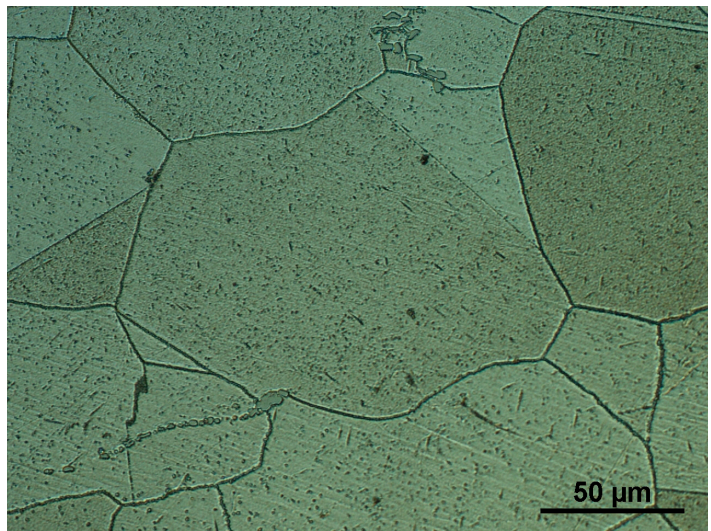

(b)

Figure 1. Sanicro 25 austenitic microstructure, etched in hydrochloric acid and hydrogen peroxide water solution, magnification (a) $50 \times$ and (b) $500 \times$.

All creep tests were performed in purified Ar 4.6 atmosphere using a lever arm (10:1) $8 \mathrm{kN}$ creep machine of IPM design for testing standard specimens. The machine was additionally equipped with special grips designed for miniature specimens. The elongation was recorded via linear variable differential transformer (LVDT), and the force was monitored by a $10 \mathrm{kN}$ load cell located on the bottom side of the load train. The LVDT is located below the load train of the creep machine and it measures the specimen elongation indirectly from the movement of the upper grip using two transmitting pullrods. The machine was equipped with a stepping motor connected with the deadweight table 
to enable constant rate experiments. In this case, a deadweight of the full capacity of the machine $(80 \mathrm{~kg}$ ) was applied. The loading rate $0.25 \mathrm{~mm} / \mathrm{min}$ was used for miniature tensile tests. Uniaxial tensile tests on standard specimens were performed in a $50 \mathrm{kN}$ electromechanical creep machine (Messphysik KAPPA 50 LA-Spring, Fürstenfeld, Austria) with Maytec furnace in Ar 5.0 atmosphere at strain rate $10^{-3} \mathrm{~s}^{-1}$. In this case a Maytec high-temperature extensometer (Singen, Germany) was used to measure the elongation of the specimen's cylindrical gauge length.

The standard specimen is shown in Figure 2a. Miniature specimens were $8 \mathrm{~mm}$ in diameter and $1 \mathrm{~mm} \pm 0.005 \mathrm{~mm}$ thick. They were prepared from a cylinder by electro discharge machining (EDM) to $1.2 \mathrm{~mm}$-thick slices and ground from both sides to final thickness under water on metallographic papers up to 2500 grit. After this, they were cut by EDM to the required shape according to Figure $2 b$.

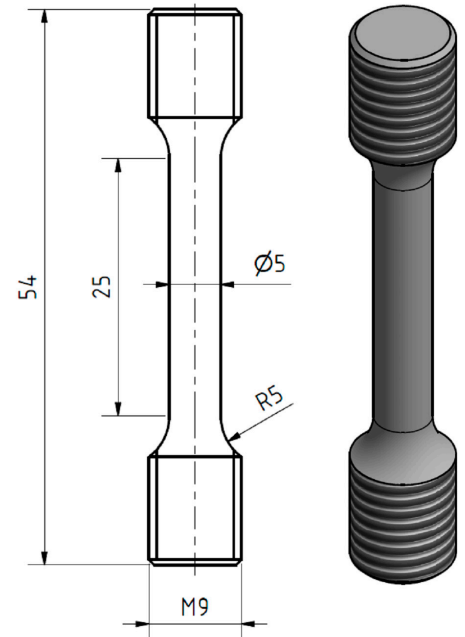

(a)
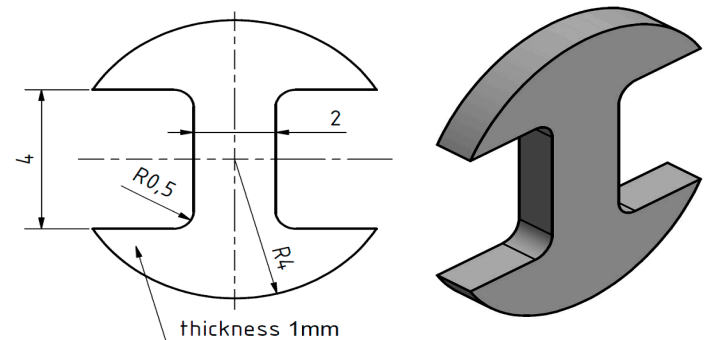

(b)

Figure 2. (a) Standard and (b) miniature tensile specimen.

The tensile tests as well as creep tests were performed one time per test condition. A larger set of specimens for testing repeatability or statistical treatment was not at our disposal. The microstructure of the studied steel was well homogenous and the consistency of the tensile and creep results presented in following indicates that the scatter should be at a low level.

\section{Results and Discussion}

\subsection{Tensile Properties}

Tensile properties at room temperature (RT) and elevated temperature $\left(700^{\circ} \mathrm{C}\right)$ were measured using both specimen geometries. As shown in Figure 3, the tensile curves differ mainly due to the method of deformation measurement (extensometer on specimen vs. extensometer on grips). This is most evident in the slope of the elastic part of the curves. The miniature specimen had a relatively small head and it visibly plastically deformed (pulled in) during the tensile test at room temperature, as shown in Figure 4 a. Such a deformation of the specimen head was not found at $700{ }^{\circ} \mathrm{C}$. Fracture surfaces of both specimens tested at RT and $700{ }^{\circ} \mathrm{C}$ showed clear signs of ductile transgranular fracture. Dimples were present in most of the fracture surface, as shown in Figure $4 b, c$ (test at RT) and Figure $5 \mathrm{a}, \mathrm{b}$ (test at $700^{\circ} \mathrm{C}$ ). However, signs of an intergranular fracture were also found as shown in Figure $5 c$, in a small location near the specimen side, which was machined by EDM. Different fracture morphology in zone 1 of about $40 \mu \mathrm{m}$ depth is visible in Figure $5 c$, which is generally considered as the zone influenced by high energy accumulation by EDM, but another zone 2 at about 80-100 $\mu \mathrm{m}$ deep clearly shows intergranular fracture morphology. This could point to a higher sensitivity of Sanicro 25 to EDM than other steels, and should be studied further. 


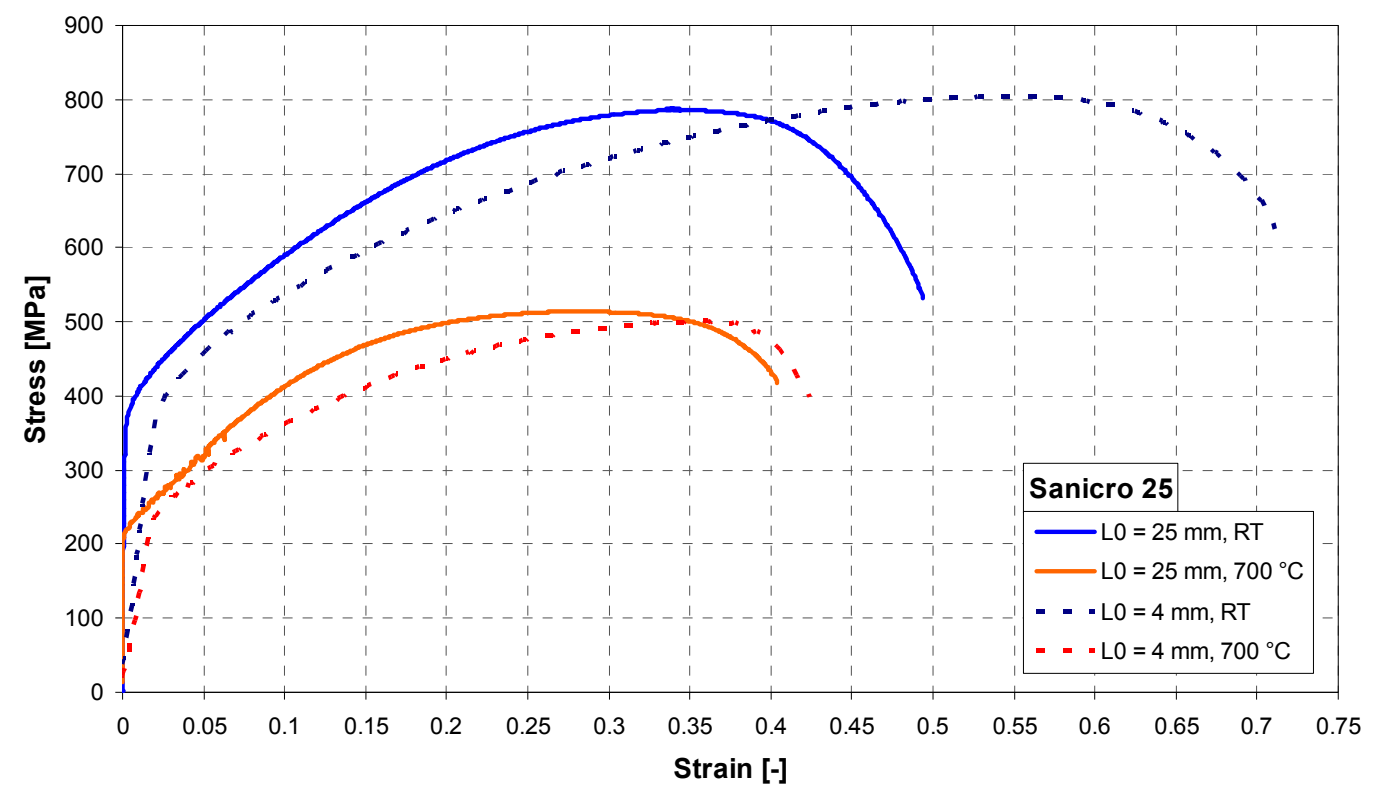

Figure 3. Tensile curves of Sanicro 25 steel.

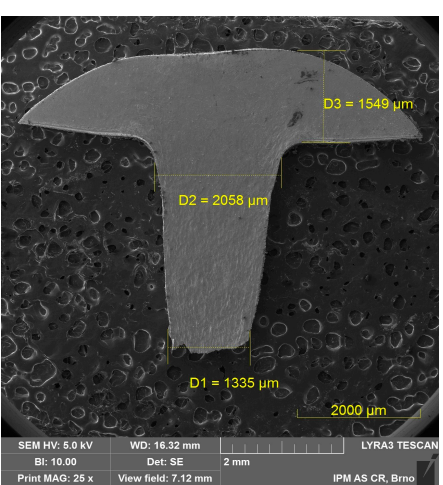

(a)

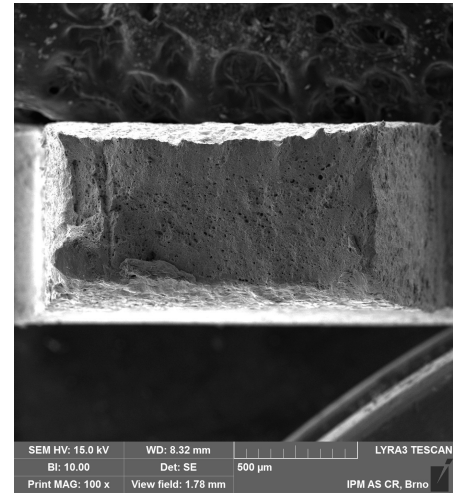

(b)

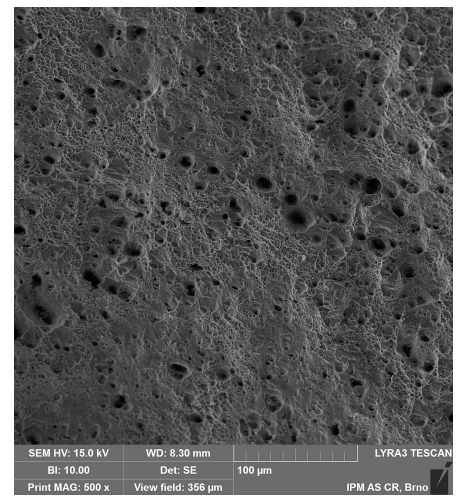

(c)

Figure 4. SEM fractographs of miniature tensile specimen tested at room temperature (RT): (a) magnification $25 \times$; (b) specimen fracture $100 \times$; (c) specimen center $500 \times$.

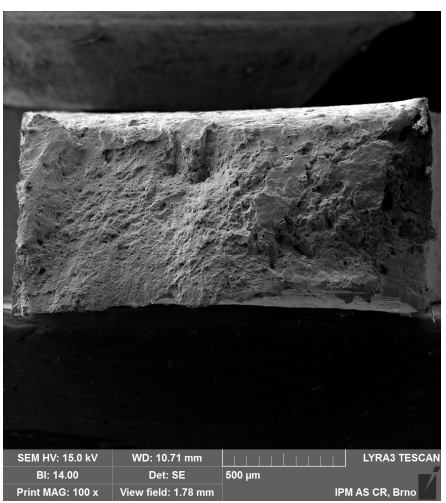

(a)

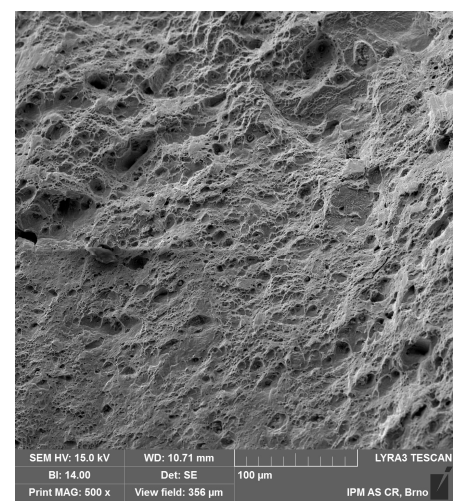

(b)

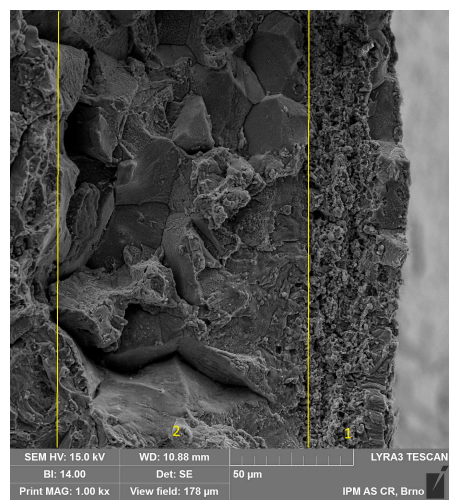

(c)

Figure 5. SEM fractographs of miniature tensile specimen tested at $700{ }^{\circ} \mathrm{C}$ : (a) specimen fracture $100 \times$; (b) specimen center $500 \times$; (c) specimen right side $1000 \times$. 
Despite these observations, the agreement of ultimate tensile and yield strength values obtained is very good, as shown in Table 2 . The ultimate tensile strength obtained was practically identical. The yield strength was identical at room temperature and less than $10 \%$ higher at $700{ }^{\circ} \mathrm{C}$. The maximum forces $F_{\mathrm{m}}$ obtained in both types of tensile tests are shown in Table 3 . The ratio of $F_{\mathrm{m}}$ for standard/miniature specimen was $\sim 10$, which is approximately the ratio of the two specimen type cross-sections $\left(19.635 \mathrm{~mm}^{2} / 2 \mathrm{~mm}^{2}=9.82\right)$.

Table 2. Results of uniaxial tensile tests at RT and $700{ }^{\circ} \mathrm{C}$.

\begin{tabular}{ccccc}
\hline Method/Condition & Ultimate Tensile Strength $\boldsymbol{R}_{\mathbf{m}} \mathbf{( M P a )}$ & Proof Yield Strength $\boldsymbol{R}_{\mathbf{p} 0.2}(\mathbf{M P a})$ \\
\hline Temperature & $\mathrm{RT}$ & $700{ }^{\circ} \mathrm{C}$ & $\mathrm{RT}$ & $700{ }^{\circ} \mathrm{C}$ \\
Miniature tensile test & 804 & 500 & 376 & 238 \\
Standard tensile test & 787 & 514 & 375 & 217 \\
Inspection certificate tensile test & 786 & 514 & 369 & 202 \\
Difference miniature vs. standard & $+2.2 \%$ & $-2.7 \%$ & $+0.3 \%$ & $+9.7 \%$ \\
\hline
\end{tabular}

Table 3. Maximum forces $F_{\mathrm{m}}$ corresponding to $R_{\mathrm{m}}$ in the uniaxial tensile tests at $\mathrm{RT}$ and $700{ }^{\circ} \mathrm{C}$.

\begin{tabular}{ccc}
\hline Method/Condition & \multicolumn{2}{c}{ Maximum Force $\boldsymbol{F}_{\mathbf{m}}(\mathbf{N})$} \\
\hline Temperature & $\mathrm{RT}$ & $700{ }^{\circ} \mathrm{C}$ \\
Miniature tensile test & 1551 & 955 \\
Standard tensile test & 15,450 & 10,086 \\
Ratio $F_{\mathrm{m}}$ standard $/ F_{\mathrm{m}}$ miniature & 9.96 & 10.56 \\
\hline
\end{tabular}

A further detailed optimization of SPT sized miniature tensile specimen geometry, especially its gauge length, cross-section, and head size, would be beneficial by finite element method and experimentally. The M-TT specimen geometry described in [21-23] seems preferable for static testing in order to avoid the excessive plastic deformation of the specimen head. Broad discussion is needed to initiate a process that would lead to the standardization of this miniature test.

\subsection{Creep}

Short-term creep testing was performed on both specimen geometries at $700{ }^{\circ} \mathrm{C}$. The creep curves and strain rate dependence on creep strain for stress between 200 to $400 \mathrm{MPa}$ are shown in Figures 6-8. Except for the test at $200 \mathrm{MPa}$, all of the tests were conducted above the yield strength of the steel. The initial strain obtained instantly after loading was subtracted, so only creep strain is plotted in the creep curves. It can be seen from Figures $6 a, 7 a, 8 a$ and $9 a$ that for all tests the time to rupture was lower for miniature specimens. Figure 9a also shows that the time to rupture at $200 \mathrm{MPa}$ is well comparable with results obtained in [24] and [27]. The creep strain rate (derivative of creep strain) is shown in Figures $6 \mathrm{~b}, 7 \mathrm{~b}$ and $8 \mathrm{~b}$. There was a higher noise for miniature specimens compared to standard specimens. This is attributed to the specimen length and given sensitivity and noise of the induction sensor recording the deformation. The stress exponent $n$ is approximately 8 for standard specimens and 7 for miniature specimens, as shown in Figure 9b. The rupture strain dependence on stress is plotted in Figure 10a. It is shown that the rupture strain steadily increases with decreasing stress. For miniature specimens, it increased less than for standard specimens. This can be attributed to small gauge length. The strain at minimum creep rate dependence on stress is plotted in Figure $10 \mathrm{~b}$. It is systematically higher for miniature specimens compared to standard specimens. Creep rupture time of the miniature specimens was in all cases approximately 30-40\% lower compared with standard specimens, and the difference slightly decreased with lower stress. This represents a certain level of conservative factor if the miniature specimen testing method is applied instead of the standard test. 


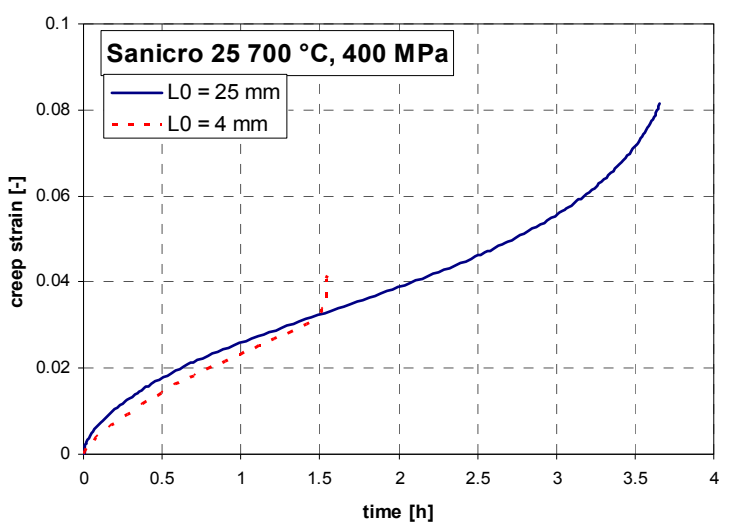

(a)

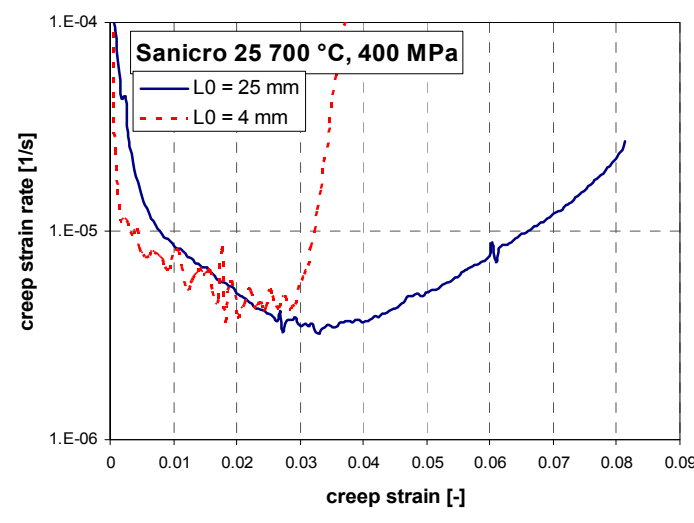

(b)

Figure 6. (a) Creep curves; (b) creep rate vs. strain relations of Sanicro 25 at $700{ }^{\circ} \mathrm{C}, 400 \mathrm{MPa}$.

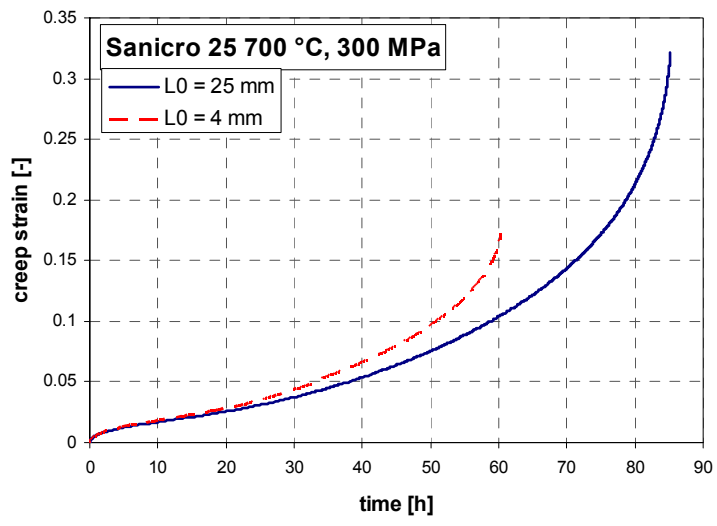

(a)

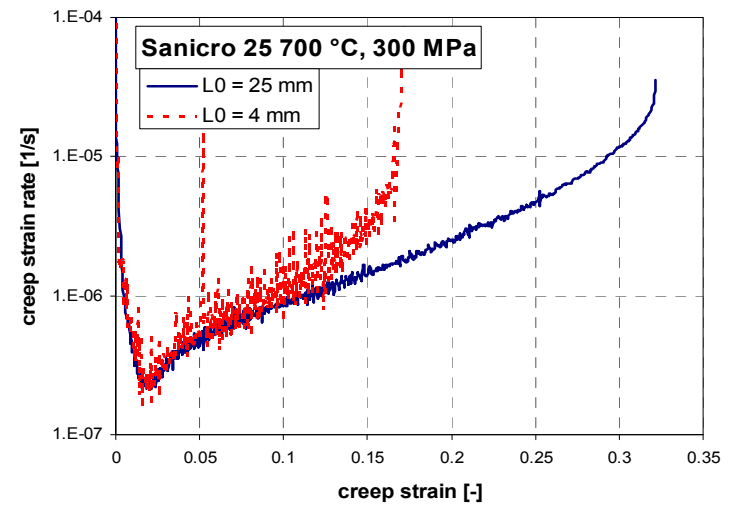

(b)

Figure 7. (a) Creep curves; (b) creep rate vs. strain relations of Sanicro 25 at $700{ }^{\circ} \mathrm{C}, 300 \mathrm{MPa}$.

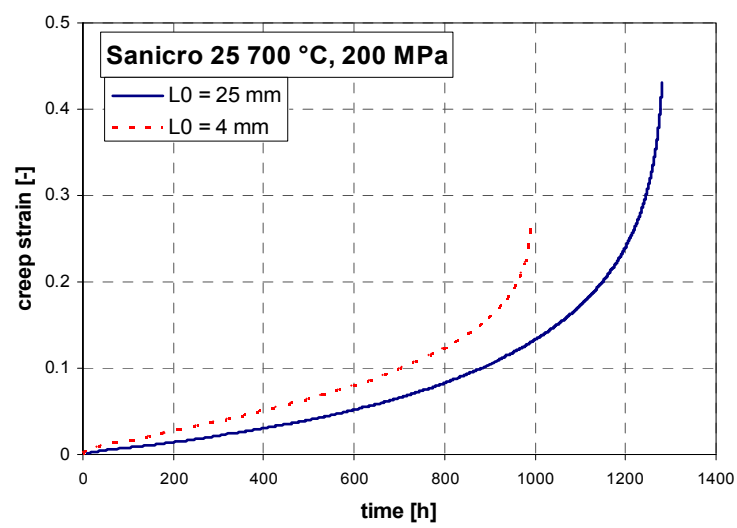

(a)

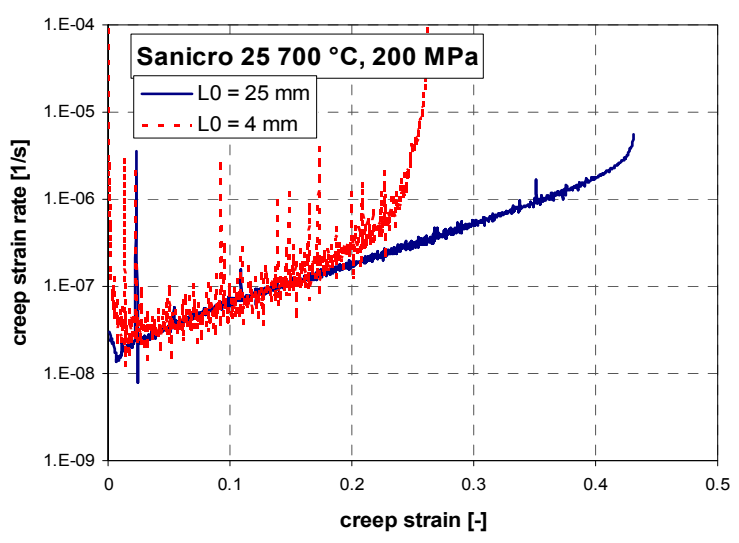

(b)

Figure 8. (a) Creep curves; (b) creep rate vs. strain relations of Sanicro 25 at $700{ }^{\circ} \mathrm{C}, 200 \mathrm{MPa}$. 


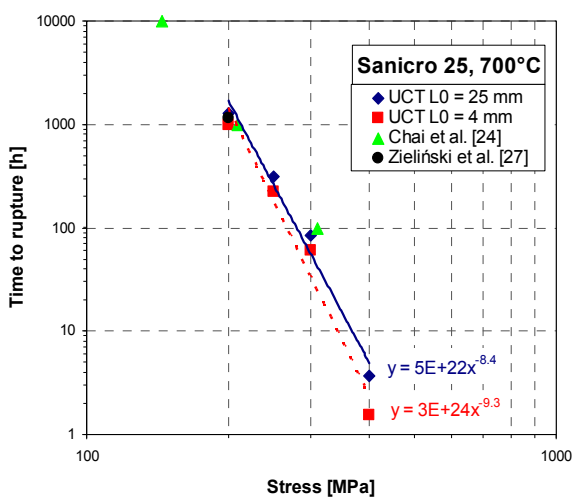

(a)

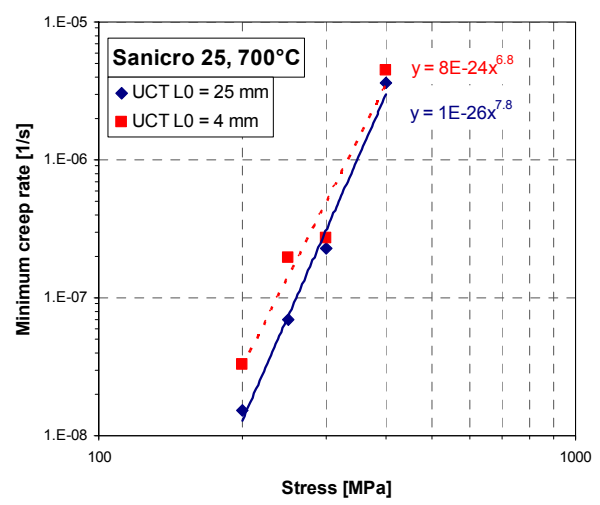

(b)

Figure 9. (a) Time to rupture dependence on stress; (b) minimum creep rate dependence on stress.

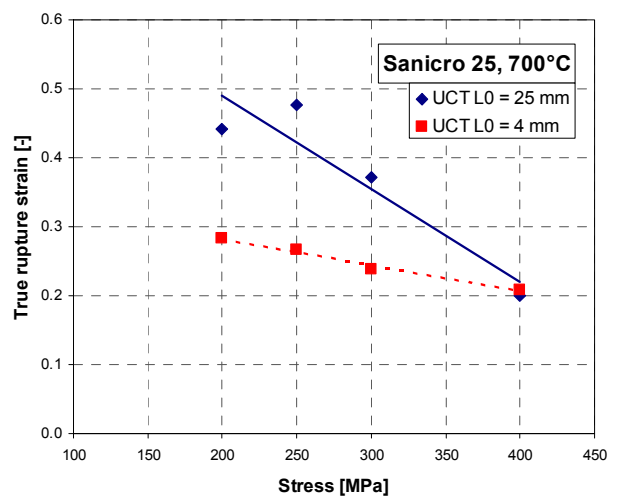

(a)

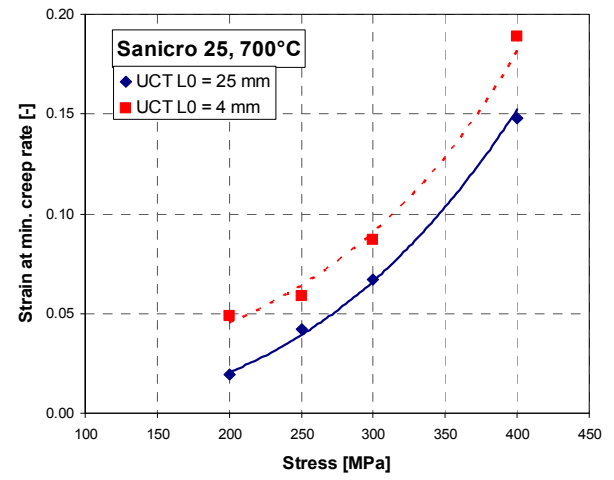

(b)

Figure 10. (a) True rupture stress dependence on applied stress; (b) strain at min. creep rate dependence on applied stress.

The fractographic analysis does not show any significant differences between the standard and miniature creep specimen fracture. Fracture morphology is mainly ductile transgranular, as shown in Figures 11 and 12. There is the presence of dimples and quasi-cleavage fracture that can also be found in other austenitic steels (e.g., 316L) [15]. However, the presence of dimples is significantly decreased in creep fracture (Figures 11 b and 12c) in comparison with tensile test fracture at high temperature (Figure 5b). The miniature specimen head visibly did not deform in the creep test as in the case of the tensile test at room temperature (Figure 12a compared to Figure 4a).

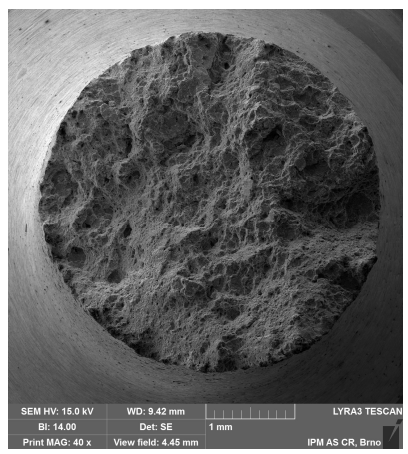

(a)

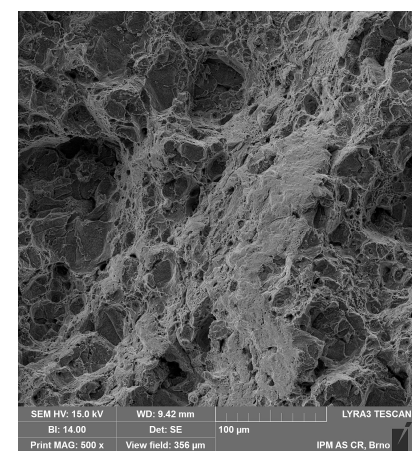

(b)

Figure 11. SEM fractographs of standard creep specimen $\left(\sigma=300 \mathrm{MPa}, T=700{ }^{\circ} \mathrm{C}, t_{\mathrm{r}}=85.2 \mathrm{~h}\right)$ : (a) fracture surface $40 \times$; (b) fracture surface $500 \times$. 


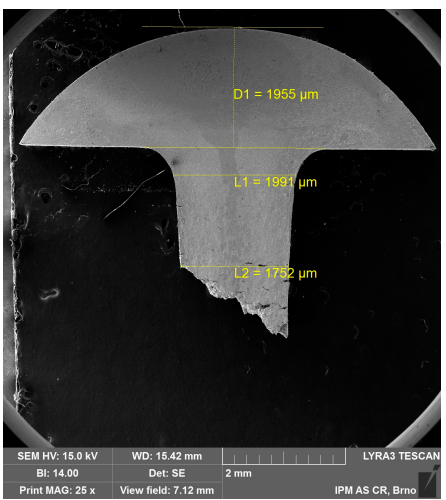

(a)

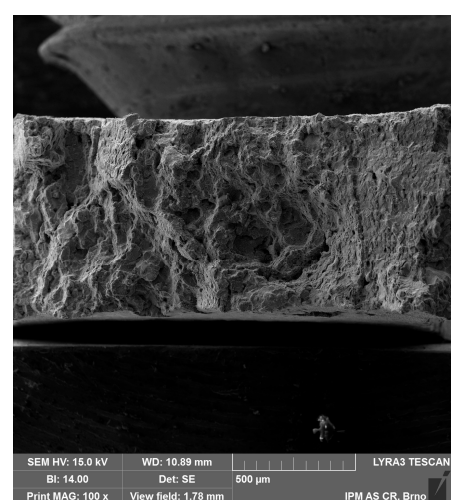

(b)

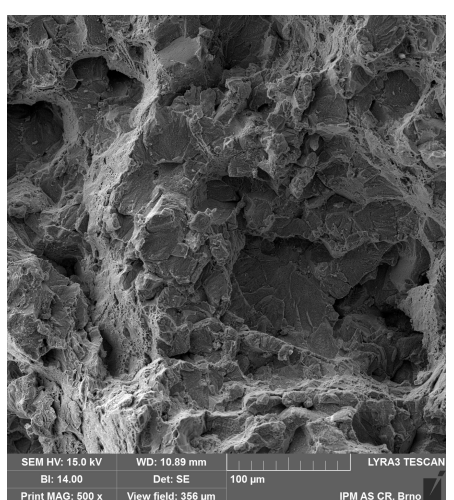

(c)

Figure 12. SEM fractographs of miniature creep specimen $\left(\sigma=300 \mathrm{MPa}, T=700{ }^{\circ} \mathrm{C}, t_{\mathrm{r}}=60.2 \mathrm{~h}\right)$ : (a) magnification $25 \times$; (b) fracture surface $40 \times$; (c) fracture surface $500 \times$.

\subsection{Perspective of Miniature Specimen Testing}

The authors believe that the results presented herein are promising. Based on these results, research should further proceed to broader studies that concentrate on: (i) optimization of specimen dimensions; (ii) testing various materials, such as ferritic-martensitic steels, austenitic steels, light alloys, and others in a similar way as SPT and SPC [8-20]; and (iii) application to practical tasks for the industry (e.g., determination of weld properties or service life extension in a similar manner as presented in $[27,30,31])$. It is necessary to define the size effect related to the particular microstructures and specimen geometry. Additionally, it is key to prove the repeatability and reproducibility of the test results on different testing machines. After successful resolution of these challenging tasks, the standardization of the miniature tensile and creep test should be feasible.

\section{Conclusions}

Conventional and miniature tensile and creep tests were applied to identify the mechanical properties of the new austenitic steel Sanicro 25 at room and elevated temperatures. Based on the comparison of both types of test results, it is possible to draw following conclusions:

- Miniature specimens can give very precise estimation of mechanical properties from a very small volume of material

- The creep life of miniature specimens was about $30-40 \%$ lower than that of standard ones, and the difference decreased with lower stress, mainly due to lower ductility

- Comparable minimum creep rates at the same stress were obtained from both types of tests

- Special care must be paid if the miniature specimens are prepared by different technology than the standard specimens (here machining and grinding vs. grinding and EDM), since changes in the fracture behavior of the steel at elevated temperature were demonstrated in a small local area.

Acknowledgments: Authors wish to thank Peter Barnard and Gerry McMillan from Doosan Babcock Energy Ltd. for supply of the experimental material. Authors greatly acknowledge Czech Science Foundation financial support of the project 15-21394S. P.D. acknowledges the use of infrastructure within the project CEITEC 2020 (LQ1601) with financial support from the Ministry of Education, Youth and Sports of the Czech Republic under the National Sustainability Programme II.

Author Contributions: F.D., M.J. and L.K. conceived and designed the experiments; M.J. and P.D. performed the experiments; M.J. and P.D. analyzed the data; P.D. performed the fractographic analysis on SEM; P.D. wrote the paper.

Conflicts of Interest: The authors declare no conflict of interest. 


\section{References}

1. Yuan, J.; Zhang, Z.L.; Su, Y.J.; Qiao, L.J.; Chu, W.Y. Influence of specimen thickness with rectangular cross-section on the tensile properties of structural steels. Mater. Sci. Eng. A 2012, 532, 601-605. [CrossRef]

2. Olbricht, J.; Bismarck, M.; Skrotzki, B. Characterization of the creep properties of heat resistant 9-12\% chromium steels by miniature specimen testing. Mater. Sci. Eng. A 2013, 585, 335-342. [CrossRef]

3. Cao, L.; Bürger, D.; Wollgramm, P.; Neuking, K.; Eggeler, G. Testing of Ni-base superalloy single crystals with circular notched miniature tensile creep (CNMTC) specimens. Mater. Sci. Eng. A 2018, 712, 223-231.

4. Kurumlu, D.; Payton, E.J.; Young, M.L.; Schöbel, M.; Requena, G.; Eggeler, G. High-temperature strength and damage evolution in short fiber reinforced aluminum alloys studied by miniature creep testing and synchrotron microtomography. Acta Mater. 2012, 60, 67-78. [CrossRef]

5. Džugan, J.; Rund, M.; Prantl, A.; Konopík, P. Mini-tensile specimen application for sheets characterization. IOP Conf. Ser. Mater. Sci. Eng. 2017, 179, 012020. [CrossRef]

6. Džugan, J.; Sibr, M.; Konopík, P.; Procházka, R.; Rund, M. Mechanical properties determination of AM components. IOP Conf. Ser. Mater. Sci. Eng. 2017, 179, 012019. [CrossRef]

7. European Committee for Standardization. Small Punch Test Method for Metallic Materials, CWA 15627. Part A: A Code of Practice for Small Punch Creep Testing and Part B: A Code of Practice for Small Punch Testing for Tensile and Fracture Behaviour, Documents of CEN WS21; European Committee for Standardization: Brussels, Belgium, 2007.

8. Milička, K.; Dobeš, F. Small punch testing of P91 steel. Int. J. Press. Vessel. Pip. 2006, 83, 625-634. [CrossRef]

9. Song, M.; Guan, K.; Qin, W.; Szpunar, J.A. Comparison of mechanical properties in conventional and small punch tests of fractured anisotropic A350 alloy forging flange. Nucl. Eng. Des. 2012, 247, 58-65. [CrossRef]

10. García, T.E.; Rodríguez, C.; Belzunce, F.J.; Suárez, C. Estimation of the mechanical properties of metallic materials by means of the small punch test. J. Alloys Compd. 2014, 582, 708-717. [CrossRef]

11. Dymáček, P.; Milička, K. Small punch testing and its numerical simulations under constant deflection force conditions. Strength Mater. 2008, 40, 24-27. [CrossRef]

12. Dymáček, P.; Seitl, S.; Milička, K.; Dobeš, F. Influence of friction on stress and strain distributions in small punch creep test models. Key Eng. Mater. 2010, 417-418, 561-564. [CrossRef]

13. Dymáček, P. Recent developments in small punch testing: Applications at elevated temperatures. Theor. Appl. Fract. Mech. 2016, 86, 25-33. [CrossRef]

14. Dobeš, F.; Dymáček, P. Fracture-based correlation of uniaxial and small punch creep data. Theor. Appl. Fract. Mech. 2016, 86, 34-38. [CrossRef]

15. Ganesh Kumar, J.; Laha, K. Small Punch Creep deformation and rupture behavior of 316L (N) stainless steel. Mater. Sci. Eng. A 2015, 641, 315-322. [CrossRef]

16. Wen, Ch.; Xu, T.; Guan, K. Correlation Factor Study of Small Punch Creep Test and Its Life Prediction. Materials 2016, 9, 796. [CrossRef] [PubMed]

17. Guan, K.; Szpunar, J.A.; Matocha, K.; Wang, D. Study on Temper Embrittlement and Hydrogen Embrittlement of a Hydrogenation Reactor by Small Punch Test. Materials 2017, 10, 671. [CrossRef] [PubMed]

18. Matocha, K.; Dorazil, O.; Hurst, R. The Present SP Tests for Determining the Transition Temperature TSP on “U” Notch Disc Specimens. Materials 2017, 10, 490. [CrossRef] [PubMed]

19. Haroush, S.; Moreno, D.; Silverman, I.; Turgeman, A.; Shneck, R.; Gelbstein, Y. The Mechanical Behavior of HAVAR Foils Using the Small Punch Technique. Materials 2017, 10, 491. [CrossRef] [PubMed]

20. Gülçimen Çakan, B.; Soyarslan, C.; Bargmann, S.; Hähner, P. Experimental and Computational Study of Ductile Fracture in Small Punch Tests. Materials 2017, 10, 1185.

21. Rund, M.; Procházka, R.; Konopík, P.; Džugan, J.; Folgar, H. Investigation of sample-size influence on tensile test results at different strain rates. Procedia Eng. 2015, 114, 410-415. [CrossRef]

22. Konopík, P.; Rund, M.; Džugan, J. Investigation of the mechanical behaviour of zirconium alloy at different strain rates using sub-size tensile specimens. In Proceedings of the 6th International Conference on Mechanics and Materials in Design, Ponta Delgada, Portugal, 26-30 July 2015; pp. 277-284.

23. Konopík, P.; Džugan, J.; Rund, M.; Procházka, R. Determination of local mechanical properties of metal components by hot micro-tensile test. In Proceedings of the International conference METAL2016, Brno, Czech Republic, 25-27 May 2016; pp. 741-746. 
24. Chai, G.; Boström, M.; Olaison, M.; Forsberg, U. Creep and LCF behaviors of newly developed advanced heat resistant austenitic stainless steel for A-USC. Procedia Eng. 2013, 55, 232-239. [CrossRef]

25. KMM-VIN. Available online: https://www.kmm-vin.info/energy-materials (accessed on 21 December 2017).

26. Polák, J.; Petráš, R.; Heczko, M.; Kuběna, I.; Kruml, T.; Chai, G. Low cycle fatigue behavior of Sanicro 25 steel at room and at elevated temperature. Mater. Sci. Eng. A 2014, 615, 175-182. [CrossRef]

27. Zieliński, A.; Dobrzański, J.; Purzyńska, H.; Sikora, R.; Dziuba-Kałuża, M.; Kania, Z. Evaluation of creep strength of heterogeneous welded joint in HR6W alloy and Sanicro 25 steel. Arch. Metall. Mater. 2017, 62, 2057-2064. [CrossRef]

28. Rutkowski, B.; Gil, A.; Czyrska-Filemonowicz, A. Microstructure and chemical composition of the oxide scale formed on the Sanicro 25 steel tubes after fireside corrosion. Corros. Sci. 2016, 102, 373-383. [CrossRef]

29. Polák, J.; Petráš, R.; Heczko, M.; Kruml, T.; Chai, G. Analysis of cyclic plastic response of heat resistant Sanicro 25 steel at ambient and elevated temperatures. Procedia Eng. 2014, 74, 68-73. [CrossRef]

30. Sroka, M.; Zieliński, A.; Dziuba-Kałuża, M.; Kremzer, M.; Macek, M.; Jasiński, A. Assessment of the Residual Life of Steam Pipeline Material beyond the Computational Working Time. Met. Basel. 2017, 7, 82. [CrossRef]

31. Zieliński, A.; Golański, G.; Sroka, M. Comparing the methods in determining residual life on the basis of creep tests of low-alloy Cr-Mo-V cast steels operated beyond the design service life. Int. J. Press. Vessel. Pip. 2017, 152, 1-6. [CrossRef]

(C) 2018 by the authors. Licensee MDPI, Basel, Switzerland. This article is an open access article distributed under the terms and conditions of the Creative Commons Attribution (CC BY) license (http:/ / creativecommons.org/licenses/by/4.0/). 